\section{Christiane Maia'}

Dirce Guilhem'

Daniel Freitas"
Departamento de Enfermagem. Faculdade de Ciências da Saúde. Universidade de Brasília. Brasília, DF, Brasil

" Gerência Geral de Sangue, outros Tecidos, Células e Órgãos. Agência Nacional de Vigilância Sanitária. Brasília, DF, Brasil

\section{Correspondence:}

Christiane Santiago Maia

SEPN 515, Edifício Ômega, $3^{\circ}$ andar sala 5

70770-502 Brasília, DF, Brasil

E-mail: csmaia2@hotmail.com

\section{Vulnerability to HIV/AIDS in married heterosexual people or people in a common-law marriage}

\begin{abstract}
OBJECTIVE: To study knowledge, preventive behavior, and perception regarding HIV/AIDS of heterosexual men and women that are married or in a common-law marriage.

METHODS: Exploratory study carried out in the Federal District of Brazil, between 2001 and 2002. Heterosexual men and women ( $N=200)$ aged 18 and 49, married or in a common-law marriage were divided into two groups: (I) 50 couples approached in public places, and (II) 100 users of a Basic Health Unit, 50 were women and 50 were men. The instrument for data collection was a semi-structured questionnaire on demographic, socioeconomic and behavioral characteristics of the interviewees, with 38 questions, two of which were open.
\end{abstract}

RESULTS: The age distribution between the groups was similar, but group I had a higher level of schooling and income, while group II had less knowledge about the ways that HIV is transmitted. The use of condoms was equally mentioned by both groups as one of the types of prevention. Of the interviewees, $14 \%$ reported its regular use in the last year. The main reasons for not using condoms were "trusting the partner" and "being incompatible with having a fixed partner". The perception of the risk of infection was more frequent among women.

CONCLUSIONS: The population studied was vulnerable to the risk of getting the disease, although the interviewees had enough knowledge on HIV/AIDS. Their perceptions of the couple reflected their acculturation in relation to gender roles and the hierarchization of the affective-sexual relationship, which can contribute to the small adoption of preventive behavior.

DESCRIPTORS: Acquired Immunodeficiency Syndrome, prevention \& control. Heterosexuality. Sexual Partners. Sexual Behavior. Health Knowledge, Practice, and Attitudes. Health Vulnerability.

\section{INTRODUCTION}

In Brazil, although there is tendency for stability of AIDS incidence, cases of HIV infection in individuals over 35 is persistently growing. ${ }^{a}$ The epidemic in the country is becoming female and heterosexual, associated with the increase in incidence among those with greater socioeconomic vulnerability. In the Brazilian Federal District (DF) 5,599 cases of AIDS have already been reported,

a Ministério da Saúde. Secretaria de Vigilância em Saúde. Programa Nacional de DST e AIDS. Boletim epidemiológico - AIDS e DST: $1^{\text {a }}$ a $26^{a}$ semana epidemiológica. Boletim epidemiológico - AIDS e DST. 2006; III(1). 
with an incidence of 19.4 cases per 100,000 inhabitants in 2006, the fifth largest in the country. ${ }^{\text {a }}$

In the last two decades, HIV/AIDS has been characterized by a dynamics of continuous transformations, raising technical and ethical dilemmas to face it and to chose the best preventive strategies for its control. ${ }^{2}$ Changes in epidemiological approaches (from "risk groups to risk behaviors” and, later to "vulnerability”) allowed to pay closer attention to society as a whole and not only as isolated groups. However, this change in viewing society was not able to make an effective change regarding the stigma associate with the disease..$^{10}$

Maybe this is because AIDS was acknowledged as an "epidemic of the immorality", since initially it was associated with people and behaviors that were considered as deviant. "Immorality epidemics" is a concept developed by Guilhem ${ }^{10}$ on the social perception of HIV/AIDS connected with metaphors such as "the gay plague" and with people initially suffering from the disease, such as prostitutes and drug users. In this sense, the moral history of AIDS enabled to build the idea that it was an "alien disease" belonging to "the others", belonging to those morally distant. However, the thin between "me" and "the other" arises when the infection goes beyond the limits of the public and the private, reaching up the sanctity of family and marriages. ${ }^{12}$ Difficulties regarding understanding the context of personal interactions still remain, especially of the factors that interfere in establishing and keeping a couple relationship and affective-sexual ties. ${ }^{12}$

Therefore, to assess HIV/AIDS prevention among heterosexual in a stable relationship faces the obstacle of how much these people are attached to beliefs and moral values associated with marriage; in the Western idea, these values present attributes such as love, faithfulness, respect, trust, and sharing. ${ }^{3,10}$ There is an assumption that when these values of the everyday life are taken upon, men and women are protected from the risk of being infected.

Difficulties coming from the hierarchization of power in affective-sexual relationship, suppressing effective communication channels on sexuality between partners result in a justification for having unsafe sex in stable relationships. ${ }^{10}$ However, the current setting of AIDS epidemics confirms that this behavior is failing and is preventing reflection on the sexuality of men and women.

The different levels and nature of individual and collective vulnerability regarding infection, getting sick, and dying from HIV, require a broad questioning on the cultural standards traditionally accepted. ${ }^{7}$ Vulnerability is understood as: "the situation resulting from a set of individual factors (biological, cognitive and behavioral), programmatic (prevention, education, control, and care programs, as well as political will), social (related to economic and social issues) and cultural (submitting to moral standards and beliefs, hierarchies, power relations, and gender issues), interdependent, and with mutual influence, taking up different weight and meanings over time and determining the level of susceptibility of individuals and groups regarding health issues”. (Guilhem, ${ }^{10}$ p. 63-64)

Few are the studies on the perception and preventing attitudes towards HIV/AIDS of men and women in stable heterosexual relationship, its interface with moralities regarding marriage and roles taken up by partners. However, recent epidemiologic data show the need for an urgent approach on the heterosexual part of the population.

The objective of the present study was to assess the knowledge on prevention and perceptions regarding HIV/AIDS of men and women married or in a common-law marriage.

\section{METHODS}

An exploratory study was conducted in a population of men and women from 18 to 49 years old, living in the Brazilian Federal District, between 2001 and 2002 that were either married or in a stable relationship. A convenience sample was used, made up by 200 individuals divided into two groups:

Group I was formed by heterosexual couples approached in public places (malls, clubs and fairs) using the snowball technique, totaling 50 pairs. The technique was to ask those surveyed names of couples, friends, and relatives to take part in the study, minimizing difficulties regarding recruiting and approaching people for interviews. ${ }^{11}$ Group II was formed by 100 unrelated users (50 men and 50 women) from a Basic Health Unit.

The instrument for data collection was a semi-structured questionnaire with 38 questions, two of which were open. There were three blocks of questions regarding demographic, socioeconomic and behavioral features of the interviewees. On the two open questions, respondents were asked to report if they used condoms, the reasons for that and the self-perception of HIV/AIDS risk accepted in a stable relationship. Closed questions were validated in previous surveys. ${ }^{10, \mathrm{~b}}$

There was no standard regarding the number of answer options in each question. Questions were grouped in

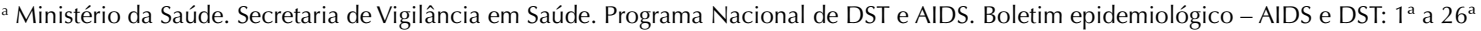
semana epidemiológica. Boletim epidemiológico - AIDS e DST. 2006;III(1).

${ }^{\text {b } F u n d a c ̧ a ̃ o ~ d o ~ B e m-E s t a r ~ F a m i l i a r ~ n o ~ B r a s i l . ~ B r a z i l: ~ N a t i o n a l ~ s u r v e y ~ o n ~ d e m o g r a p h y ~ a n d ~ h e a l t h . ~ B r a s i ́ l i a: ~} 1997$.
} 
intervals or simple categories. Univariate statistical analysis was performed using chi-square test and Fisher's exact test, with a 5\% significance level using EpiInfo 6.0 program. Answers to the open questions were used to exemplify some data.

This study has been approved by the Ethical Research Committee of the Health Secretariat of the Brazilian Federal District (CEP-SES/DF). All participants gave their written consent.

\section{RESULTS}

Table 1 presents sociodemographic characteristics and length of affective-sexual relationship of individuals according to the group.

Regarding knowledge on HIV/AIDS transmission, sexual relationship was identified as a source of infection for almost all individuals (Table 2). Transfusion and using non-disposable syringe/needles were reported in greater proportion by group I than group II $(p<0.001$ and $\mathrm{p}=0.046$, respectively). Living with people with HIV and kissing on the lips were also mentioned as ways for transmitting the virus (Table 3), this last one was more significantly mentioned by Group II ( $p=0.005)$.

The use of condoms was equally reported as a preventive measure by both groups (95\%). Caution regarding blood transfusion and use of disposable syringe/needles were proportionally more commonly reported by Group I than Group II $(\mathrm{p}<0.001$ and $\mathrm{p}=0.002$, respectively) (Table 2).

Figure 1 presents the places and means of communication most commonly mentioned by interviewees on source of information about HIV/AIDS.

The use of condoms in all relations in the last 12 months was reported by $14 \%$ of individuals. There was no significant difference between time living together with partner and condom use.

According to Figure 2, 34 (17\%) individuals reported extramarital sex in the last 12 months, of whom, 24 (71\%) were male. Among interviewees that had extramarital sex, $9 \%$ did not use condoms.

In the open questions, most men (20 from group I and 10 from group II) reported not using condoms with their partners because it would be incompatible with having a fixed sexual partner, as illustrated by this report: "I see no need. I only have one partner". Among women, the most frequent justification (24\%) was trust in their partners, as shown by this report "We have a relationship based on trust and love. I am taking the risk". Only one woman reported the use of condoms to prevent sexually transmitted diseases, such as AIDS. Other arguments included: use of another contraceptive method, the partner dislike for using condoms, and previous HIV test, which made the relationship safe.
Table 1. Sociodemographic characterization according to groups I and II studied. Brazilian Federal District, 20012002.

\begin{tabular}{|c|c|c|}
\hline \multirow{2}{*}{ Variable } & \multicolumn{2}{|c|}{ Groups (\%) } \\
\hline & I & II \\
\hline \multicolumn{3}{|l|}{ Age group (years) } \\
\hline $18-24$ & 25 & 21 \\
\hline $25-29$ & 17 & 31 \\
\hline $30-34$ & 23 & 19 \\
\hline $35-39$ & 21 & 14 \\
\hline $40-49$ & 14 & 15 \\
\hline \multicolumn{3}{|l|}{ Schooling (finished) } \\
\hline Elementary School & 0 & 55 \\
\hline High school & 50 & 40 \\
\hline University & 37 & 3 \\
\hline Post Graduation & 13 & 0 \\
\hline Unknown & 0 & 2 \\
\hline \multicolumn{3}{|l|}{ Place of residence } \\
\hline City & 56 & 5 \\
\hline Outskirts (metropolitan area) & 44 & 95 \\
\hline \multicolumn{3}{|l|}{ Monthly income (R\$) } \\
\hline No income & 18 & 20 \\
\hline $1-500$ & 10 & 54 \\
\hline $501-1,000$ & 13 & 16 \\
\hline $1,001-2,000$ & 19 & 7 \\
\hline Over 2,000 & 40 & 3 \\
\hline \multicolumn{3}{|l|}{ Religion } \\
\hline Roman Catholic & 62 & 64 \\
\hline Evangelical & 5 & 20 \\
\hline Spiritual Kardecist & 9 & 2 \\
\hline Protestant & 5 & 2 \\
\hline Not religious & 9 & 10 \\
\hline Other & 10 & 2 \\
\hline \multicolumn{3}{|l|}{ Marital Status } \\
\hline Widow/er & 0 & 1 \\
\hline Divorced & 4 & 5 \\
\hline Separated & 2 & 0 \\
\hline Single & 32 & 49 \\
\hline Married & 62 & 45 \\
\hline \multicolumn{3}{|c|}{ Time living with current partner (years) } \\
\hline Up to 1 & 13 & 12 \\
\hline $1-5$ & 48 & 37 \\
\hline$>5-15$ & 30 & 39 \\
\hline$>15$ & 9 & 12 \\
\hline
\end{tabular}

About the self-perception on the risk of getting HIV, because they were in a stable affective-sexual partnership, $71 \%$ of women answered affirmatively, compared to $44 \%$ of men. The following reports show this 
Table 2. Frequency of correct answers on HIV prevention and transmission according to Groups I and II studied. Brazilian Federal District, 2001-2002.

\begin{tabular}{lcc}
\hline & \multicolumn{2}{c}{$\begin{array}{c}\text { Groups } \\
\text { Correct answer }\end{array}$} \\
& I & II \\
\hline Type of transmission & & \\
$\quad$ Sexual intercourse & 100 & 97 \\
Blood transfusion (receving blood) & 88 & 47 \\
Use of non-disposable syringe/needles & 63 & 49 \\
Form of prevention & & \\
$\quad$ Use of condoms & 95 & 95 \\
Care with blood transfusion & 50 & 9 \\
Use disposable syring/needles & 59 & 38 \\
\hline
\end{tabular}

Table 3. Frequency of incorrect answers on HIV transmission and prevention according to Groups I and II studied. Brazilian Federal District, 2001-2002.

\begin{tabular}{llc}
\hline Incorrect answer & \multicolumn{2}{c}{ Groups } \\
& I & II \\
\hline Form of transmission & & \\
$\quad$ Kissing on the lips & 2 & 12 \\
$\quad$ Living with infected people & 0 & 5 \\
$\quad$ Mosquito bite & 2 & 0 \\
Form of prevention & & \\
$\quad$ Having one partner & 16 & 9 \\
\hline
\end{tabular}

self-perception. "To what extent can I trust my life to a person, and to what extent will I live my life suspecting?" questioned one interviewee; another interviewee reported: "Indeed there is risk, if I don't think about my marriage and do something stupid".

\section{DISCUSSION}

Limitations of the present study are: different selection processes, use of convenience sample, that is, which is not representative of the general population. However, because it was an exploratory survey, the study aimed at making more explicit the problem, favoring understanding of the issue.

Group I presented greater schooling and income. The form of sexual transmission of HIV is equally known by the two groups, whereas the other aspects demonstrated that the group with lower schooling had less information.

Parker \& Camargo ${ }^{18}$ (2000) highlighted that AIDS has been directed to the less favored segments of society, and to Fernandes, ${ }^{4}$ (1998) that fact that the disease reached more and more people with lower schooling, is due to the reduced access to information. The same

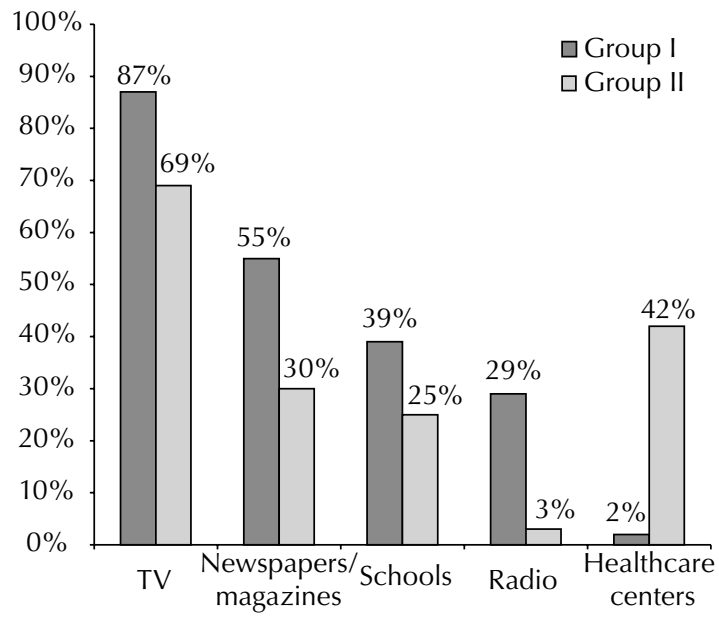

Figure 1. Sources of information on HIV/AIDS most commonly mentioned according to groups I and II studied. Brazilian Federal District, 2001- 2002.

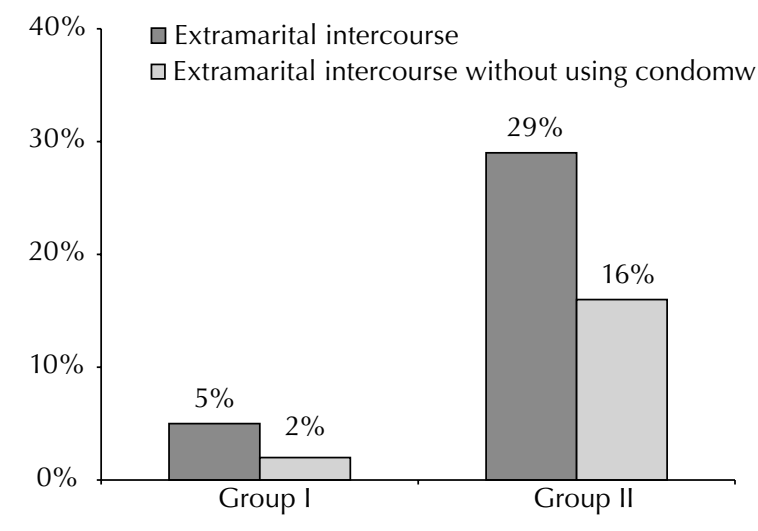

Figure 2. Frequency of extramarital sex without condoms according to groups I and II studied. Brazilian Federal District, 2001-2002.

ways of transmission and prevention among women in the present study were observed by Grimberg ${ }^{9}$ (2001). Vieira et $\mathrm{al}^{20}$ (2000) observe that men had knowledge on AIDS transmission, and $97 \%$ said that sexual relation is a way of transmitting HIV.

The influence of the environment in which individuals were submitted to questionnaires can be noticed by the answers on the use of condoms. Individuals of the survey approached in the health unit (group II) may have mentioned the use of condoms more frequently because of the doctor's power, ${ }^{6}$ as a way to meet the interviewers' expectations.

Restricted use of condoms was common to the groups, both in marital and extramarital relationships. Historically, the use of condoms was associated with prostitution, promiscuity, and extramarital relations, 
restricting its use. Despite the significant increase in its use in Brazil between the years of 1998 and 2004, its adherence is smaller among women, black, illiterate and in the Mid-West region. ${ }^{17}$

Regarding sources of information on HIV/AIDS, there is the need for the effective participation of the media in education intervention regarding HIV/AIDS prevention, because they have a significant role on the construction of social and individual values. ${ }^{19}$ Meyer et $\mathrm{al}^{15}$ (2004) considered that television adds on HIV/ AIDS reproduce or broadcast multiple gender representations, unstable and conflicting, excluding those who are not identified in these descriptions. Gonçalves \& Varandas $^{8}$ (2005) propose a bioethical agreement with the media so that moral dilemma related to AIDS can be suitably dealt with.

Schools and teachers appear as important channels to spread information. According to data of the Ministry of Education and Culture ${ }^{16}$ (2005), 60.2\% of the schools in the country have actions to prevent sexually transmitted diseases and AIDS. However, it is disturbing that only $29.3 \%$ of the teachers are skilled for it. ${ }^{16}$

The increased number of individuals from Group II that acquired knowledge on the disease in health units is due to the fact that interviews with these subjects were performed in a Basic Health Unit, becoming, therefore, a selection bias.

For Berquó, ${ }^{1}$ (2000) the difference between one night stand among genders is a result of different views on the need of sexual-affective relations. Female sexuality is still seen as limited to its reproductive function, and male sexuality is undisciplined and incoherent. ${ }^{a}$

For Macklin ${ }^{14}$ (2003), women are more vulnerable to AIDS due to their social and economical place in society, hindering them to negotiate the use of condoms, discuss about fidelity, and leave relationships that put them at risk. Feelings of helplessness are noticed and also dilemma reported by women that express a fatal conception of the disease, against which nothing can be done.

Vieira et $\mathrm{al}^{20}$ (2000) pointed out the risks to which men are exposed to, since many have several partners and do no use condoms. As previously described in a report, there is still the idea that AIDS is limited to certain groups, being a disease outside their context. Thus, preventive measures are not adopted by these individuals that do not see themselves as risk group.
Additionally, men only feel they are in risk of getting HIV outside the household environment.

HIV/AIDS is still seen as "street disease" or "disease of the others". ${ }^{10}$ Therefore, there is little discussion on the issue among couples. Gender representations are observed on the speech of the interviewees, as well as cultural values regarding love and fidelity, expressed, for example by the "myth of the romantic love" ${ }^{3}$ as an essential attribute of happiness. This romantic and eternal view of love may make couples stop using condoms and believe that they are really protected against HIV/AIDS.

Heterosexual men and women interviewed in the present study, married or in common-law marriage, have important knowledge on HIV/AIDS transmission, however, their marital perceptions express the culture they are inserted in regarding gender roles and hierarchization of the affective-sexual relationship. This may explain restriction to the adoption of preventive behavior, making them vulnerable to HIV infection.

There are categories of vulnerability to HIV infection in the present study. Preventive behaviors, even those known by individuals, are not practiced in most situations (individual vulnerability). Income and gender inequalities interfere both for acquiring information and for decision making in AIDS prevention (social vulnerability). Culturally established male and female role interfere considerably on the decision about HIV/AIDS prevention by individuals (cultural vulnerability).

Therefore, there is need for empowering couples, understood as the expansion of freedom of choice and ability to act on the resources affecting their lives. ${ }^{13}$ Empowering is an essential tool for overcoming gender inequality. ${ }^{13}$

Prevention policies towards HIV/AIDS must take into account that the epidemics lies on inequalities, affecting populations heterogeneously. ${ }^{5}$ Stigmas, taboos, and prejudice regarding the disease establish a family and social organization in which speeches of power, especially in marital relations, influence collective answers to the epidemics. Campaigns geared to couples in stable relationships are necessary and must consider social values that hinder the adoption of preventive practices of individuals. It is imperative, therefore, that those in charge of health area use the media consciously to control the epidemics, enlarging the individual, social, cultural, and political dimension of the subjects.

${ }^{a}$ Reis AL. Mulheres e AIDS: rompendo o silêncio através da adesão de um centro municipal de saúde [dissertação de mestrado]. Rio de Janeiro: Universidade Federal do Rio de Janeiro; 2001. 


\section{REFERENCES}

1. Berquó $\mathrm{E}$, coordenador. Comportamento sexual da população brasileira e percepções do HIV/Aids. Brasília: Ministério da Saúde; 2000. p.249-50. (Série Avaliação, 4).

2. Castilho EA, Bastos FI, Szwarcwald CL, Fonseca MGP. A AIDS no Brasil: uma epidemia em mutação. Cad Saude Publica. 2000;16(suppl 1):S04-5.

3. Costa JF. Nem fraude nem favor: estudos sobre o amor romântico. Rio de Janeiro: Rocco; 1998.

4. Fernandes JCL. Evolução dos conhecimentos, atitudes e práticas relativas ao HIV/AIDS em uma população de favela do Rio de Janeiro. Cad Saude Publica. 1998;14(3):575-81.

5. Galvão J. Aids no Brasil: a agenda de construção de uma epidemia. Rio de Janeiro: ABIA/São Paulo: Editora 34; 2001

6. Gilbert ACB, Cardoso MHCA, Wuillaume SM. Médicos residentes e suas relações com/e no mundo da saúde e da doença: um estudo de caso institucional com residentes em obstetrícia/ginecologia. Interface (Botucatu). 2006;10(19):103-16

7. Gonçalves EH, Guilhem D. Leitura bioética das campanhas educativas governamentais de prevenção ao HIV/Aids e sua aplicabilidade às mulheres casadas. O Mundo da Saúde. 2003;27(2):292-300.

8. Gonçalves EH, Varandas R. O papel da mídia na prevenção do HIV/Aids e a representação da mulher no contexto da epidemia. Cienc Saude Coletiva. 2005;10(1):229-35.

9. Grimberg M. "Saber de SIDA" y cuidado sexual em mujeres jóvenes de sectores populares del cordón sur de la ciudad de Buenos Aires: apuntes para la definición de políticas de prevención. Cad Saude Publica. 2001;17(3):481-9.

10. Guilhem D. Escravas do Risco: bioética, mulheres e Aids. Brasília: Editora UnB/Finatec; 2005.
11. Jiménez AL, Gotlieb SLD, Hardy H, Zaneveld LJD. Prevenção de doenças sexualmente transmissíveis em mulheres: associação com variáveis sócio-econômicas e demográficas. Cad Saude Publica. 2001;17(1):55-62.

12. Knauth DR. O vírus procurado e o vírus adquirido: a construção da identidade entre mulheres portadoras do vírus da Aids. Rev Estudos Feministas. 1997b;5(2):291300 .

13. Léon M. Empoderamiento: relaciones de las mujeres con el poder. Rev Estudos Feministas. 2000;8(2):191205.

14. Macklin R. Bioethics, vulnerability, and protection. Bioethics. 2003;5-6(17):472-85.

15. Meyer DE, Santos LHS, Oliveira DL, Wilhelms DM. "Mulher sem-vergonha" e "traidor responsável": problematizando representações de gênero em anúncios televisivos oficiais de prevenção ao HIV/ AIDS. Rev Estudos Feministas. 2004;12(2):51-76.

16. Ministério da Educação e Cultura. Censo Escolar, INEP. 2005 apud Paiva V, Pupo LR, Barboza R. O direito à prevenção e os desafios da redução da vulnerabilidade ao HIV no Brasil. Rev Saude Publica. 2006;40(Supl):109-19.

17. Paiva $V$, Pupo LR, Barboza R. O direito à prevenção e os desafios da redução da vulnerabilidade ao HIV no Brasil. Rev Saude Publica. 2006;40(Supl):109-19.

18. Parker R, Camargo KR. Pobreza e HIV/AIDS: aspectos antropológicos e sociológicos. Cad Saude Publica. 2000;16(1):89-102.

19. Trindade MP, Schiavo MR. Comportamento sexual das mulheres em relação a HIV/Aids. DST- J Bras Doenças Sex Transm. 2001;13:17-22.

20. Vieira EM, Villela WV, Réa MF, Fernandes MEL, Franco E, Ribeiro G. Alguns aspectos do comportamento sexual e prática de sexo seguro em homens de Município de São Paulo. Cad Saude Publica. 2000;16(4):997-1009.

C Maia was supported by the Conselho Nacional de Desenvolvimento Científico e Tecnológico (CNPq -National Counsel of Technological and Scientific Development; scientific initiation scholarship). 